\title{
Interleukin 13 as a Biomarker for Parasite Resistance in Goats Naturally Exposed to Haemonchus contortus
}

\author{
M. M. Corley ${ }^{1} \&$ A. A. Jarmon ${ }^{1}$ \\ ${ }^{1}$ Agriculture Research Station, Virginia State University, Virginia 23806, USA \\ Correspondence: Michelle M. Corley, P.O. Box 9061, Agriculture Research Station, Virginia State University, \\ Virginia 23806, USA. Tel: 804-524-6802/5890. E-mail: mcorley@vsu.edu.
}

Received: February 27, 2012 Accepted: March 14, 2012 Online Published: May 22, 2012

doi:10.5539/jas.v4n7p31 URL: http://dx.doi.org/10.5539/jas.v4n7p31

The authors would like to thank the Virginia State University Animal Care and laboratory staff (Joni Collins, Amanda Miller, Roslyn Stein and Edwina Westbrook). This research was funded by USDA-EVANS ALLEN at the Virginia State University Agriculture Research Station, Journal Article Series Number 290, Virginia.

\begin{abstract}
Gut expulsion of some mammalian nematodes requires IL-13 secreted by Th2 cells. Interleukin 13 enhances gut contractions and glycoprotein hyper-secretion that propel parasites to detach from the gut wall. Haemonchus contortus is a gastrointestinal blood sucking nematode of small ruminants. This study evaluated expression of IL-13 in selected parasite resistant Spanish and Myotonic goats. Whole blood, and abomasal and intestinal tissues were harvested from goats exhibiting susceptibility and resistance to Haemonchus contortus through standard and molecular detection methods. An indirect Enzyme Linked Immunosorbent Assay was performed to determine IL-13 expression. Results showed that IL-13 was expressed 70\% more in intestinal than abomasal tissues. Parasite resistant goats expressed more IL-13 than susceptible goats. These data indicate that IL-13 expression may be useful as a biomarker for resistance to Haemonchus contortus infection in goats, allowing IL-13 based anthelmintic drug development and goat producers the ability to select parasite resistant animals.
\end{abstract}

Keywords: Haemonchus contortus, resistance, interleukin 13, goat

\section{Introduction}

Gastrointestinal nematode (GIN) infection continues to be a major constraint on the efficient production of small ruminant livestock throughout the world (Abebe, Gebreyohannes, Mekuria, Abunna, \& Regassa, 2010; Poglayen \& Battelli, 2006; Terrill, Miller, Burke, Mosjidis, \& Kaplan, 2011; Veneziano, 2004). In the US alone, losses incurred as the result of GIN, including the costs of treatment, are likely to reach millions per year. The greatest economic importance are those species that elicit weak protective immune responses especially Haemonchus contortus in sheep and goats. Since the abomasum of ruminants is a poor immune effector lymphoid organ (Gasbarre, 1997), it is not surprising that the GINs that reside in the abomasum are the most pathogenic and most difficult to raise a protective immune response against. Haemonchus contortus causes a disease known as haemonchosis in all domesticated ruminants (Asanji, 1988; Hogg et al., 2010; Roberts \& Swan, 1982a, 1982b; van Wyk \& Bath, 2002). Young animals are most susceptible, become heavily infected, and manifest anemia, hypoproteinemia and edema. The hyperacute phase animals experience severe anemia with dark colored feces, which ends in death through severe blood loss. The average blood loss has been calculated at $0.05 \mathrm{ml} /$ parasite/day, and blood first appears in feces 6 to 12 days after infection. This translated in loss/head in an animal shedding 10,000 eggs/day, equals 500ml of blood loss/day (Clark, Kiesel, \& Goby, 1962; Le Jambre, 1995; Rowe, Nolan, de Chaneet, Teleni, \& Holmes, 1988). During the life cycle of Haemonchus contortus the female lays an estimated 10,000 eggs per day. These pass with the feces onto the grounds and become infective larvae (L3) in 4-6 days if the environment is favorable (warm temperature, soil moisture and relative humidity) (Wharton, 1982, 1991; Wharton \& Sommerville, 1984). After ingestion of L3 larvae, exsheathment occurs in the rumen and the larvae migrate to the abomasum and penetrate the gastric epithelial cells. From there they emerge as stage 4 larvae (L4). Both adults and L4 stages of Haemonchus contortus in sheep and goats suck blood of the animal, leaving hemorrhage wounds in the abomasal mucosa. The mechanism of gut expulsion of nematodes is gaining much attention since it has been implicated in host resistance to GIN (Artis, 2006; Bancroft, Artis, Donaldson, Sypek, \& Grencis, 2000; Cliffe et 
al., 2005; Horsnell et al., 2007). Interleukin 13 is one of the cytokines implicated in the response to mucosal infection (Kasaian et al., 2007; Wynn, 2003), however the specific role of IL-13 in the immune response to GIN infection has been identified in mice (Akiho, Blennerhassett, Deng, \& Collins, 2002; Bancroft et al., 2000; Barner, Mohrs, Brombacher, \& Kopf, 1998; Grencis \& Bancroft, 2004; Madden et al., 2002; McKenzie, Bancroft, Grencis, \& McKenzie, 1998; Urban et al., 1998; Wynn, 2003; Zhao et al., 2003). It has been shown that IL-13 alters intestinal epithelial cell function through induction of smooth muscle hypercontraction (Akiho et al., 2002)and goblet cell hyperplasia (Khan, Blennerhasset, Ma, Matthaei, \& Collins, 2001). The mechanism of immunity to GIN infection in small ruminant is not well understood. Sheep cells recirculating in afferent and efferent lymph seem to consistently express the IL-13 gene after experimental infection with GIN(Pernthaner, Cole, Morrison, \& Hein, 2005). During GIN infection, Th2 cells produce IL-13 which induces epithelial cell repair and mucus production. Increased cell turnover stimulates contraction and removal of parasitized epithelial cells. Mucus production hinders attachment of the GIN to the gut wall and accelerates expulsion of the parasite (Artis, 2006; Bancroft et al., 2000; Horsnell et al., 2007; McKenzie et al., 1998; Urban et al., 1998; Zhao et al., 2003). Very few studies have examined the immune protective role of IL-13 and its relationship to resistance of small ruminants to Haemonchus contortus, (Jasmer, Lahmers, \& Brown, 2007; Lacroux et al., 2006; Robinson, Pleasance, Piedrafita, \& Meeusen, 2011; Terefe et al., 2009) and the innate and or adaptive immune mechanism involved. Therefore, this study evaluated IL-13 expression in intestinal tissues of goats pasture exposed to Haemonchus contortus.

\section{Materials and Methods}

\subsection{Animals and Screening for Parasite Load}

Spanish and myotonic goats were housed at VSU Randolph farm in accordance with animal care and use guidelines. Over 100 animals grazing pasture were screened for parasite load via FEC using a modification of the McMaster technique (Cringoli, Rinaldi, Veneziano, Capelli, \& Scala, 2004). In brief, fresh rectal fecal samples were collected into sterile bags and stored at $-80^{\circ} \mathrm{C}$ for molecular analysis. Strongyle/Trichostrongyle eggs (80-90 microns) were counted at a 10X microscopic magnification and eggs per gram EPG (total eggs X 50) determined. Blood samples were collected and analyzed for PCV via the micro-hematocrit method (Strumia, Sample, \& Hart, 1954). Clinical anemia status was determined using FAMACHA eye color chart scores $(<3=$ normal, 4 or $5=$ anemia). The EPG, FAM and PCV data collected were analyzed using SAS version 9.1.3, (Cary, North Carolina) to ultimately group goats into high and low infection groups and to correlate these with GIN susceptibility ( $>2000$ EPG with PCV $\leq 18)$ and resistance ( $>2000$ EPG with PCV $\geq 18$ ) groups. From the animals screened, 38 were selected and placed into naturally resistant and susceptible groups. Nine animals from resistant and susceptible groups were sacrificed and abomasal and intestinal tissue samples collected in sterile PBS and stored at $-80^{\circ} \mathrm{C}$.

\subsection{Verification of Haemonchus Contortus spp. in Goat Feces}

Genomic DNA was extracted using a modification of the QIAamp DNA stool kit (Qiagen). In brief, 180-220 mg stool was weighed in a $2 \mathrm{ml}$ microcentrifuge tube and placed on ice, and homogenized with lysis buffer provided in the kit. The stool mixture was then heated for $5 \mathrm{~min}$ at $70^{\circ} \mathrm{C}$, vortexed for 5 seconds and centrifuged at $13000 \mathrm{rpm}$ for 1 minute. A fraction of the supernatant $(1.2 \mathrm{ml})$ was transferred to a new $2 \mathrm{ml}$ tube and the pellet discarded appropriately. The remaining steps were carried out according to the manual. The purity and yield of the fecal DNA was measured using a Nanodrop UV Spectrophotometer (Thermoscientific) and subsequently stored at $-20^{\circ} \mathrm{C}$ for molecular identification of Haemonchus contortus. Molecular detection and gene sequence verification of Haemonchus contortus was conducted as previously published (Corley \& Jarmon, 2012). Nucleotide sequences were analyzed using sequence analysis software (NCBI-BLAST, CLC Main Workbench).

\subsection{Abomasal and Intestinal Tissue Collection and Preparation}

Animals were sacrificed in accordance with national humane euthanasia guidelines and abomasal (full thickness from the abomasal wall to include lymph nodes) and intestinal (jejunal) tissues collected in sterile PBS and placed at $-80^{\circ} \mathrm{C}$ for further analysis. Abomasal and intestinal tissues were homogenized in sterile PBS, centrifuged at $10,000 \mathrm{~g}$ and supernatants collected for ELISA assay.

\subsection{IL-13 Goat Tissue ELISA}

An indirect IL-13 ELISA assay was performed using a Bovine IL-13 ELISA kit (Bethyl Laboratories Inc.). Procedures were carried out according to instructions. Briefly, $100 \mu \mathrm{l}$ of homogenized abomasal and intestinal samples were added to each well. Serial dilutions of IL-13 pure protein were prepared as directed to generate standard curves for quantitation of IL-13. Samples (triplicate) were read in an iMark microplate reader (BioRad) at 
$450 \mathrm{~nm}$. Standard curves were generated using the microplate manager 6 software and concentrations of IL-13 determined. Data were exported for statistical analysis.

\section{Statistical Analysis}

All data were analyzed using the General Linear Model procedure of SAS. To account for trial $(n=3)$ differences, the data were analyzed in a Randomized Complete Block Design. Means were considered significant at the 5\% level of probability.

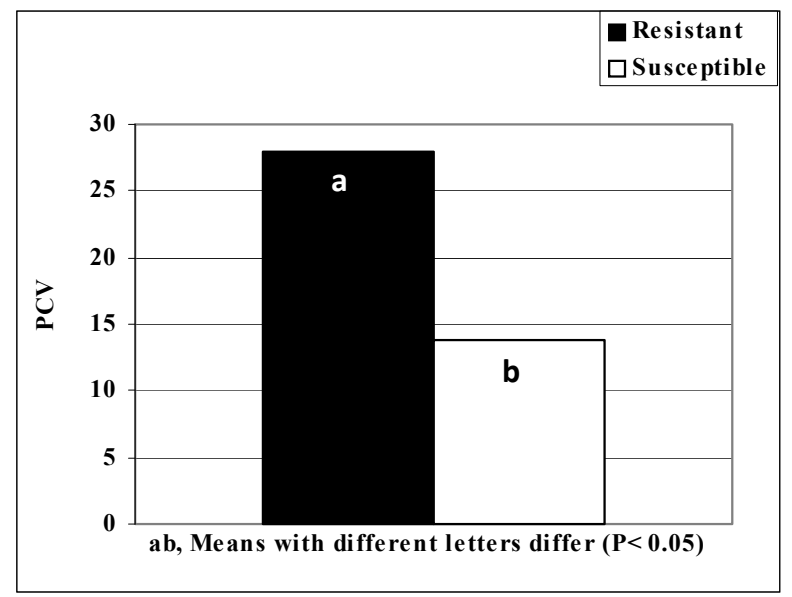

Figure 1A. Grouping of Haemonchus contortus Susceptible and Resistant Goats Relative to Packed Cell Volume

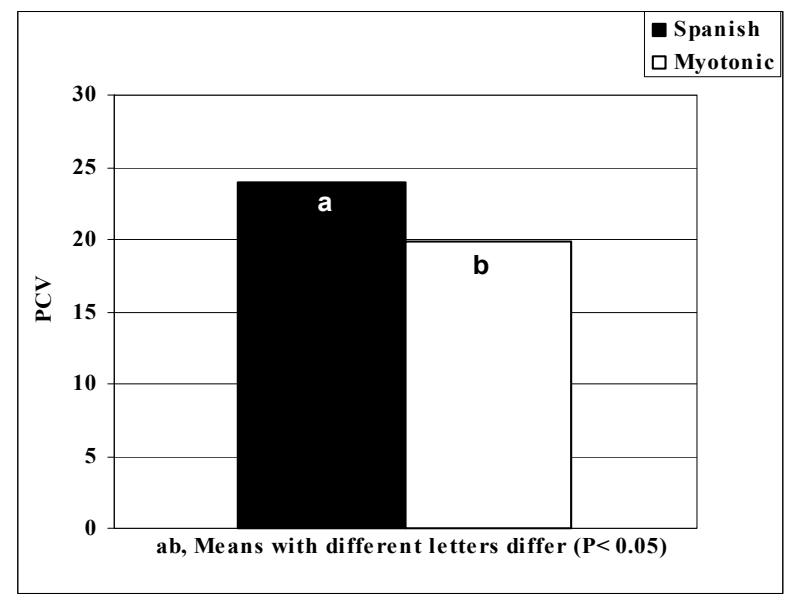

Figure 1B. Packed Cell Volume (PCV) in Goats Pasture Exposed to Haemonchus contortus Relative to Breed

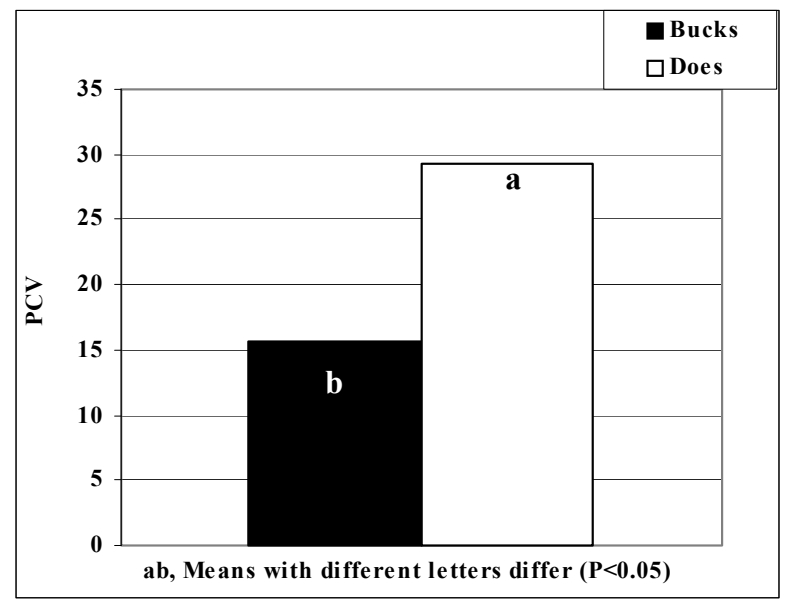

Figure 1C. Packed Cell Volume (PCV) in Goats Pasture Exposed to Haemonchus contortus Relative to Gender 


\section{Results and Discussion}

Many approaches to determine host gastrointestinal parasite resistance in small ruminants have been explored (Hoste \& Torres-Acosta, 2011; Knox, Torres-Acosta, \& Aguilar-Caballero, 2006; Preston \& Allonby, 1978; Vlassoff, Bisset, \& McMurtry, 1999; Woolaston \& Baker, 1996). In this study, more than 200 (Spanish and Myotonic) goats on Virginia State University Randolph farm, that were naturally exposed to Haemonchus contortus were screened and goats simultaneously exhibiting an anthelmintic treatable FEC $(\geq 2000)$ and a normal PCV $(>18)$ were placed in the resistant $(>2000$ FEC and $>18$ PCV) category. Goats exhibiting a high FEC and a low PCV were placed in the susceptible $(>2000 \mathrm{FEC}$ and PCV $\leq 18)$ category. In addition, we reviewed the fecal molecular quantitation data of Haemonchus contortus (Corley \& Jarmon, 2012) to support grouping into resistant and susceptible groups. Goats in susceptible and resistant groups were significantly $(\mathrm{P}<0.05)$ different (Figures $1 \mathrm{~A}$, and $2 \mathrm{~A}$ ), indicating that the criteria used to determine susceptibility and resistance to Haemonchus contortus was valid. Goats that exhibited a high FEC and a high PCV inferred that there was inherent resistance of goats to Haemonchus contortus. Goats screened also showed that within susceptible and resistant groups, Spanish goats had higher $(\mathrm{P}<0.05) \mathrm{PCV}$ and Bucks were more $(\mathrm{P}<0.05)$ susceptible (low PCV and high FEC) to Haemonchus contortus infection, (Figure 1B-1C and 2B-2C). Significant differences in FEC between Spanish and Myotonic goats were not evident $(\mathrm{P}>0.05)$ (Figure $2 \mathrm{~B}$ ). This could be the result of the initial bias in the grouping criteria of resistant and susceptible goats. Use of the bovine IL-13 antibody was successful in detection of the goat IL-13 in both abomasal and intestinal tissues of parasite resistant and susceptible goats. This was indicative of sequence conservation between the goat and bovine IL-13 as was demonstrated among other mammalian species at both the genomic and proteomic levels (Avery et al., 2004; Ohtani, Hayashi, Hashimoto, Nakanishi, \& Dijkstra, 2008; Zarlenga, Dawson, Kringel, Solano-Aguilar, \& Urban, 2004). Higher $(\mathrm{P}<0.05)$ IL-13 was expressed in intestinal vs. abomasal tissue (Figure 4). Since the abomasum is a poor immune effector organ (Gasbarre, 1997), it is difficult to attribute much of the IL-13 response to Haemonchus contortus to the abomasum. It however helps us to infer that the IL-13 response in Haemonchus contortus infection is largely attributed to the intestine. Regardless of breed and gender, there was higher $(\mathrm{P}<0.05) \mathrm{IL}-13$ expression in intestinal tissue of the resistant group of goats (Figure 3A). This cytokine response coincides with other studies that demonstrate upregulation of IL-13 in GIN resistance (Bancroft et al., 2000; Grencis \& Bancroft, 2004; Morimoto et al., 2009; Zaros et al., 2010). However, within resistant and susceptible groups, Spanish goats expressed more $(\mathrm{P}<0.05)$ intestinal IL-13 than Myotonic goats (Figure 3B), which correlates with Spanish goats showing higher PCV than Myotonic goats. The FEC and PCV data showed that males are more susceptible than females to Haemonchus contortus infection. Studies on GIN infection also show gender plays a role in susceptibility (Bancroft et al., 2000; Idris, Moors, Sohnrey, \& Gauly, 2011). However, in this study, Bucks expressed more $(\mathrm{P}<0.05)$ intestinal IL-13 than Does (Figure 3C), which contradicted the observation that IL-13 upregulation is correlated with resistance to GIN infection. This implies that the phenomenon of the cytokine response to GIN resistance may be more complex when gender is taken into consideration. Past studies have shown that androgens play a role in Th2 responses to GIN infection in mice, and that the cytokine expression profile is different in susceptible males versus females (Hepworth, Hardman, \& Grencis, 2010). This phenomenon may have critical implications for the development and efficacy of potential therapeutic anthelmintic drugs and vaccines. Interleukin 13 is not the only cytokine involved in the immune response to GIN infection (Akiho et al., 2002; Bancroft et al., 2000; Barner et al., 1998; Helmby, Takeda, Akira, \& Grencis, 2001; Zhao et al., 2003). Interleukins 4, 5 and 9 have been implicated in the immune response to GIN infection. We focused on IL-13 in this work to determine its suitability as a biomarker for Haemonchus contortus resistance. Ultimately the long term application is to use cytokines involved in the rejection of GIN as foci for drug and vaccine development, especially those that enhance gut nematode expulsion (Artis, 2006; Faulkner, Humphreys, Renauld, Van Snick, \& Grencis, 1997; Hasnain et al., 2011; Humphreys, Xu, Hepworth, Liew, \& Grencis, 2008; Khan et al., 2005; Khan et al., 2003; Maizels \& Holland, 1998).

\section{Conclusion}

These data indicate that the immune protective mechanism of IL-13 in goats pasture exposed to Haemonchus contortus remains complex but is definitely a promising biomarker to discern the mechanism of the immune response to Haemonchus contortus infection in goats. Further studies on the mechanism of IL-13 in naïve goats challenged with Haemonchus contortus and IL-13 expression monitored over time need to be performed. Focus on IL-13 as a useful biomarker for resistance to Haemonchus contortus infection in goats, will enable IL-13 based anthelmintic drug or vaccine development and goat producers the ability to select parasite resistant animals. 


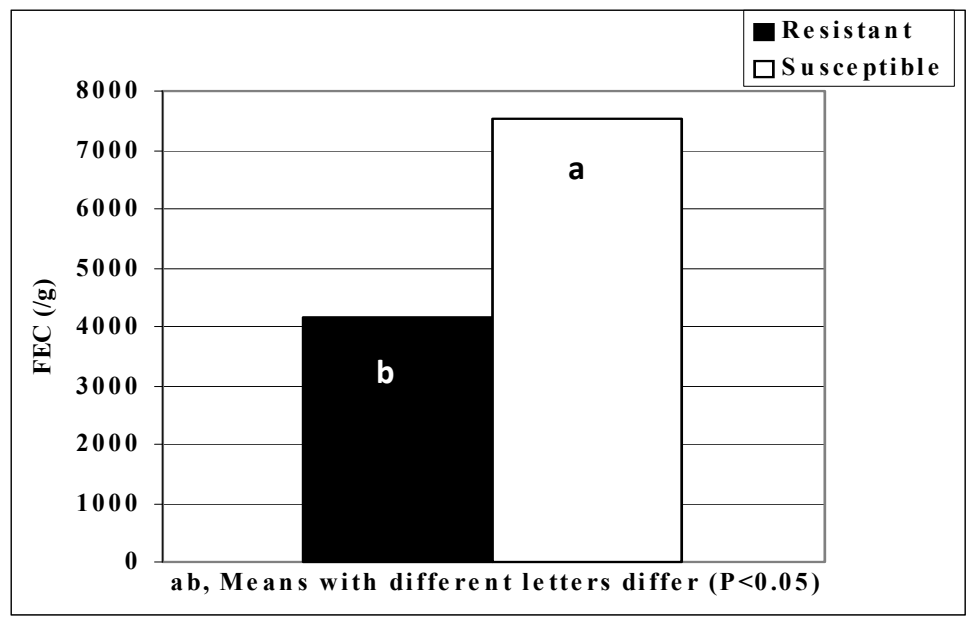

Figure 2A. Grouping of Haemonchus contortus Susceptible and Resistant Goats Relative to Fecal Egg Counts (FEC)

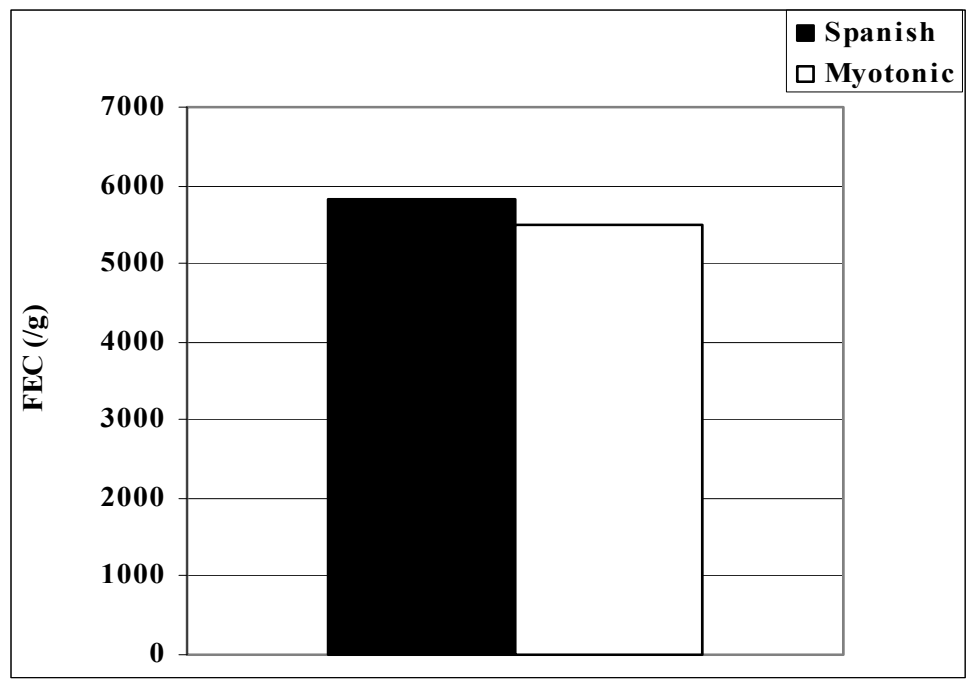

Figure 2B. Fecal Egg Counts (FEC) in Goats Pasture Exposed to Haemonchus contortus Relative to Breed

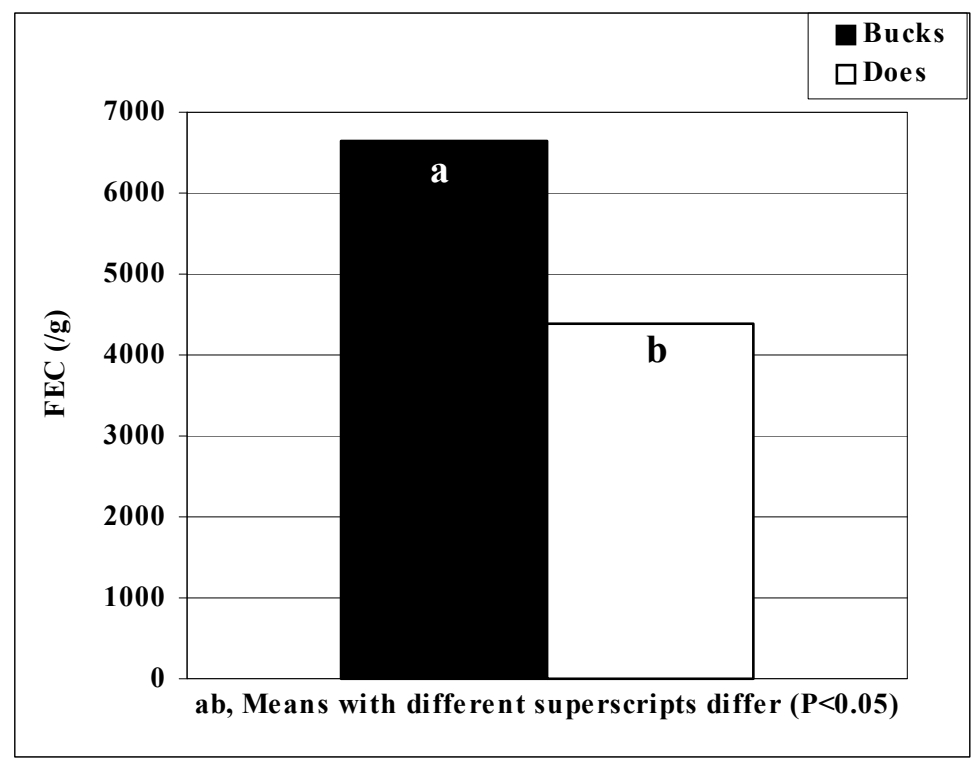

Figure 2C. Fecal Egg Counts (FEC) in Goats Pasture Exposed to Haemonchus contort s Relative to Gender 


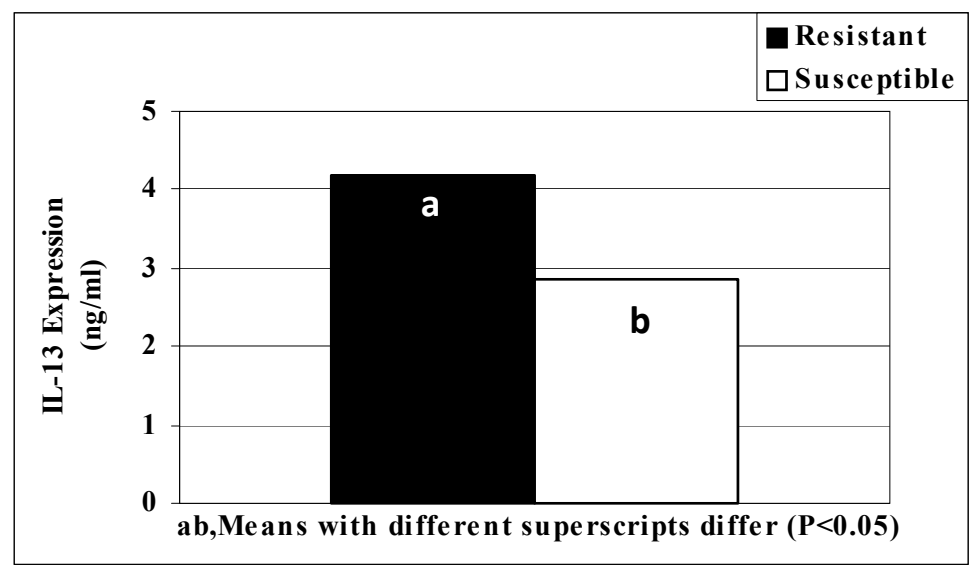

Figure 3A. IL-13 Expression in Haemonchus contortus Susceptible and Resistant Goats

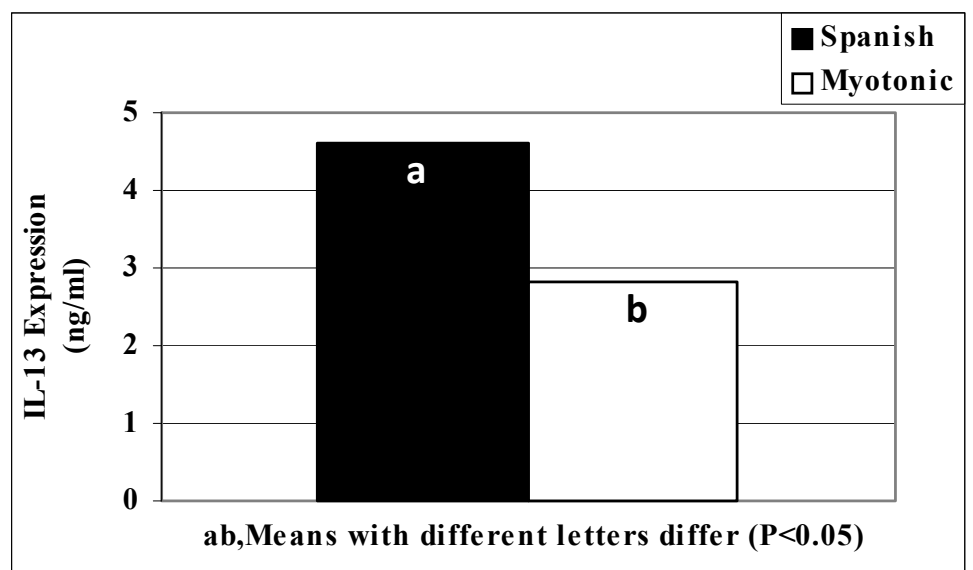

Figure 3B. IL-13 Expression in Intestine of Goats Pasture Exposed to Haemonchus contortus Relative to Breed

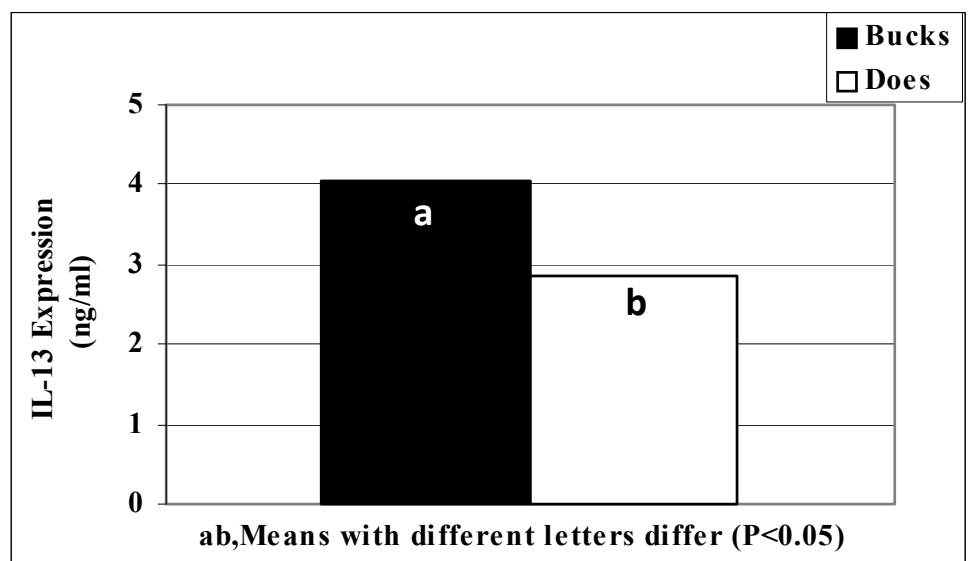

Figure 3C. IL-13 Expression in Intestine of Goats Pasture Exposed to Haemonchus contortus Relative to Gender 


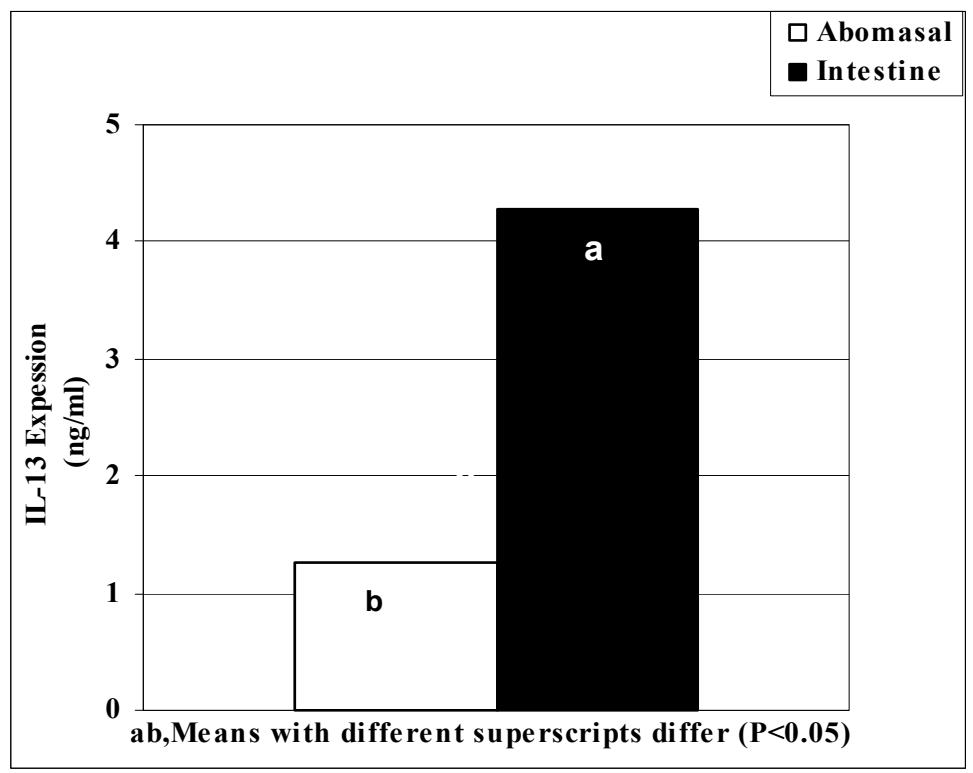

Figure 4. IL-13 Expression in Abomasal and Intestinal Tissues of Goats Pasture Exposed to Haemonchus contortus

\section{References}

Abebe, R., Gebreyohannes, M., Mekuria, S., Abunna, F., \& Regassa, A. (2010). Gastrointestinal nematode infections in small ruminants under the traditional husbandry system during the dry season in southern Ethiopia. Trop Anim Health Prod, 42(6), 1111-1117. doi: 10.1007/s11250-010-9532-3

Akiho, H., Blennerhassett, P., Deng, Y., \& Collins, S. M. (2002). Role of IL-4, IL-13, and STAT6 in inflammation-induced hypercontractility of murine smooth muscle cells. Am J Physiol Gastrointest Liver Physiol, 282(2), G226-232.

Artis, D. (2006). New weapons in the war on worms: identification of putative mechanisms of immune-mediated expulsion of gastrointestinal nematodes. Int $J$ Parasitol, 36(6), 723-733. http://dx.doi.org/S0020-7519(06)00068-3 [pii]10.1016/j.ijpara.2006.02.011

Asanji, M. F. (1988). Haemonchosis in sheep and goats in Sierra Leone. J Helminthol, 62(3), 243-249.

Avery, S., Rothwell, L., Degen, W. D., Schijns, V. E., Young, J., Kaufman, J., \& Kaiser, P. (2004). Characterization of the first nonmammalian T2 cytokine gene cluster: the cluster contains functional single-copy genes for IL-3, IL-4, IL-13, and GM-CSF, a gene for IL-5 that appears to be a pseudogene, and a gene encoding another cytokine like transcript, KK34. J Interferon Cytokine Res, 24(10), 600-610.

Bancroft, A. J., Artis, D., Donaldson, D. D., Sypek, J. P., \& Grencis, R. K. (2000). Gastrointestinal nematode expulsion in IL-4 knockout mice is IL-13 dependent. Eur J Immunol, 30(7), 2083-2091. http://dx.doi.org/10.1002/1521-4141(200007)30:7<2083::AID-IMMU2083>3.0.CO;2-3

Barner, M., Mohrs, M., Brombacher, F., \& Kopf, M. (1998). Differences between IL-4R alpha-deficient and IL-4-deficient mice reveal a role for IL-13 in the regulation of Th2 responses. Curr Biol, 8(11), 669-672. http://dx.doi.org/S0960-9822(98)70256-8 [pii]

Clark, C. H., Kiesel, G. K., \& Goby, C. H. (1962). Measurements of blood loss caused by Haemonchus contortus infection in sheep. Am J Vet Res, 23, 977-980.

Cliffe, L. J., Humphreys, N. E., Lane, T. E., Potten, C. S., Booth, C., \& Grencis, R. K. (2005). Accelerated intestinal epithelial cell turnover: a new mechanism of parasite expulsion. Science, 308(5727), 1463-1465. http://dx.doi.org/308/5727/1463

Corley, M., \& Jarmon, A. (2012). A Common Beta Tubulin Isotype-1 Gene Single Nucleotide Polymorphism as a Tool for Detection and Quantitation of Anthelmintic Resistant Haemonchus contortus in Grazing Goats. Journal of Agricultural Science, 4(No. 6. June), in Press. 
Cringoli, G., Rinaldi, L., Veneziano, V., Capelli, G., \& Scala, A. (2004). The influence of flotation solution, sample dilution and the choice of McMaster slide area (volume) on the reliability of the McMaster technique in estimating the faecal egg counts of gastrointestinal strongyles and Dicrocoelium dendriticum in sheep. Vet Parasitol, 123(1-2), 121-131. http://dx.doi.org/S0304401704002377

Faulkner, H., Humphreys, N., Renauld, J. C., Van Snick, J., \& Grencis, R. (1997). Interleukin-9 is involved in host protective immunity to intestinal nematode infection. Eur $J$ Immunol, 27(10), 2536-2540. http://dx.doi.org/10.1002/eji.1830271011

Gasbarre, L. C. (1997). Effects of gastrointestinal nematode infection on the ruminant immune system. Vet Parasitol, 72(3-4), 327-337; discussion 337-343. http://dx.doi.org/S0304-4017(97)00104-0 [pii]

Grencis, R. K., \& Bancroft, A. J. (2004). Interleukin-13: a key mediator in resistance to gastrointestinal-dwelling nematode parasites. Clin Rev Allergy Immunol, 26(1), 51-60. http://dx.doi.org/CRIAI:26:1:51

Hasnain, S. Z., Evans, C. M., Roy, M., Gallagher, A. L., Kindrachuk, K. N., Barron, L., . . Thornton, D. J. (2011). Muc5ac: a critical component mediating the rejection of enteric nematodes. J Exp Med, 208(5), 893-900. http://dx.doi.org/jem.20102057

Helmby, H., Takeda, K., Akira, S., \& Grencis, R. K. (2001). Interleukin (IL)-18 promotes the development of chronic gastrointestinal helminth infection by downregulating IL-13. J Exp Med, 194(3), 355-364.

Hepworth, M. R., Hardman, M. J., \& Grencis, R. K. (2010). The role of sex hormones in the development of Th2 immunity in a gender-biased model of Trichuris muris infection. Eur $J$ Immunol, 40(2), 406-416. http://dx.doi.org/10.1002/eji.200939589

Hogg, R., Whitaker, K., Collins, R., Holmes, P., Mitchell, S., Anscombe, J., . . Gilleard, J. (2010). Haemonchosis in large ruminants in the UK. Vet Rec, 166(12), 373-374. http://dx.doi.org/166/12/373-a

Horsnell, W. G., Cutler, A. J., Hoving, J. C., Hoving, C. J., Mearns, H., Myburgh, E., . . Brombacher, F. (2007). Delayed goblet cell hyperplasia, acetylcholine receptor expression, and worm expulsion in SMC-specific IL-4Ralpha-deficient mice. PLoS Pathog, 3(1), e1. http://dx.doi.org/06-PLPA-RA-0111R2

Hoste, H., \& Torres-Acosta, J. F. (2011). Non chemical control of helminths in ruminants: adapting solutions for changing worms in a changing world. Vet Parasitol, 180(1-2), 144-154. http://dx.doi.org/S0304-4017(11)00388-8

Humphreys, N. E., Xu, D., Hepworth, M. R., Liew, F. Y., \& Grencis, R. K. (2008). IL-33, a potent inducer of adaptive immunity to intestinal nematodes. J Immunol, 180(4), 2443-2449.

Idris, A., Moors, E., Sohnrey, B., \& Gauly, M. (2011). Gastrointestinal nematode infections in German sheep. Parasitol Res. http://dx.doi.org/10.1007/s00436-011-2648-1

Jasmer, D. P., Lahmers, K. K., \& Brown, W. C. (2007). Haemonchus contortus intestine: a prominent source of mucosal antigens. Parasite Immunol, 29(3), 139-151. http://dx.doi.org/10.1111/j.1365-3024.2006.00928.x

Kasaian, M. T., Donaldson, D. D., Tchistiakova, L., Marquette, K., Tan, X. Y., Ahmed, A., . . Abraham, W. M. (2007). Efficacy of IL-13 neutralization in a sheep model of experimental asthma. Am J Respir Cell Mol Biol, 36(3), 368-376. http://dx.doi.org/10.1165/rcmb.2006-0244OC

Khan, W. I., Blennerhasset, P., Ma, C., Matthaei, K. I., \& Collins, S. M. (2001). Stat6 dependent goblet cell hyperplasia during intestinal nematode infection. Parasite Immunol, 23(1), 39-42.

Khan, W. I., Motomura, Y., Blennerhassett, P. A., Kanbayashi, H., Varghese, A. K., El-Sharkawy, R. T., . . Collins, S. M. (2005). Disruption of CD40-CD40 ligand pathway inhibits the development of intestinal muscle hypercontractility and protective immunity in nematode infection. Am J Physiol Gastrointest Liver Physiol, 288(1), G15-22. http://dx.doi.org/10.1152/ajpgi.00159.2004

Khan, W. I., Richard, M., Akiho, H., Blennerhasset, P. A., Humphreys, N. E., Grencis, R. K., . . Collins, S. M. (2003). Modulation of intestinal muscle contraction by interleukin-9 (IL-9) or IL-9 neutralization: correlation with worm expulsion in murine nematode infections. Infect Immun, 71(5), 2430-2438.

Knox, M. R., Torres-Acosta, J. F., \& Aguilar-Caballero, A. J. (2006). Exploiting the effect of dietary supplementation of small ruminants on resilience and resistance against gastrointestinal nematodes. Vet Parasitol, 139(4), 385-393. http://dx.doi.org/10.1016/j.vetpar.2006.04.026 
Lacroux, C., Nguyen, T. H., Andreoletti, O., Prevot, F., Grisez, C., Bergeaud, J. P., . . J Jacquiet, P. (2006). Haemonchus contortus (Nematoda: Trichostrongylidae) infection in lambs elicits an unequivocal Th2 immune response. Vet Res, 37(4), 607-622. http://dx.doi.org/10.1051/vetres:2006022

Le Jambre, L. F. (1995). Relationship of blood loss to worm numbers, biomass and egg production in Haemonchus infected sheep. Int J Parasitol, 25(3), 269-273. http://dx.doi.org/0020751994001188 [pii]

Madden, K. B., Whitman, L., Sullivan, C., Gause, W. C., Urban, J. F., Katona, I. M., . . Shea-Donohue, T. (2002). Role of STAT6 and mast cells in IL-4- and IL-13-induced alterations in murine intestinal epithelial cell function. J Immunol, 169(8), 4417-4422.

Maizels, R. M., \& Holland, M. J. (1998). Parasite immunology: pathways for expelling intestinal helminths. Curr Biol, 8(20), R711-714.

McKenzie, G. J., Bancroft, A., Grencis, R. K., \& McKenzie, A. N. (1998). A distinct role for interleukin-13 in Th2-cell-mediated immune responses. Curr Biol, 8(6), 339-342.

Morimoto, M., Zhao, A., Sun, R., Stiltz, J., Madden, K. B., Mentink-Kane, M., . . Shea-Donohue, T. (2009). IL-13 receptor alpha2 regulates the immune and functional response to Nippostrongylus brasiliensis infection. J Immunol, 183(3), 1934-1939. http://dx.doi.org/10.4049/jimmunol.0804299

Ohtani, M., Hayashi, N., Hashimoto, K., Nakanishi, T., \& Dijkstra, J. M. (2008). Comprehensive clarification of two paralogous interleukin 4/13 loci in teleost fish. Immunogenetics, 60(7), 383-397. http://dx.doi.org/10.1007/s00251-008-0299-x

Pernthaner, A., Cole, S. A., Morrison, L., \& Hein, W. R. (2005). Increased expression of interleukin-5 (IL-5), IL-13, and tumor necrosis factor alpha genes in intestinal lymph cells of sheep selected for enhanced resistance to nematodes during infection with Trichostrongylus colubriformis. Infect Immun, 73(4), 2175-2183. http://dx.doi.org/10.1128/IAI.73.4.2175-2183.2005

Poglayen, G., \& Battelli, G. (2006). [An insight into the epidemiology and economic impact of gastro-intestinal nematodes in small ruminants]. Parassitologia, 48(3), 409-413.

Preston, J. M., \& Allonby, E. W. (1978). The influence of breed on the susceptibility of sheep and goats to a single experimental infection with Haemonchus contortus. Vet Rec, 103(23), 509-512.

Roberts, J. L., \& Swan, R. A. (1982a). Quantitative studies of ovine haemonchosis. 2. Relationship between total worm counts of Haemonchus contortus, haemoglobin values and bodyweight. Vet Parasitol, 9(3-4), 201-209.

Roberts, J. L., \& Swan, R. A. (1982b). Quantitative studies of ovine haemonchosis. 3. The interpretation and diagnostic significance of the changes in serial egg counts of Haemonchus contortus in a sheep flock. Vet Parasitol, 9(3-4), 211-216.

Robinson, N., Pleasance, J., Piedrafita, D., \& Meeusen, E. N. (2011). The kinetics of local cytokine and galectin expression after challenge infection with the gastrointestinal nematode, Haemonchus contortus. Int $J$ Parasitol, 41(5), 487-493. http://dx.doi.org/10.1016/j.ijpara.2010.11.006

Rowe, J. B., Nolan, J. V., de Chaneet, G., Teleni, E., \& Holmes, P. H. (1988). The effect of haemonchosis and blood loss into the abomasum on digestion in sheep. Br J Nutr, 59(1), 125-139.

Strumia, M. M., Sample, A. B., \& Hart, E. D. (1954). An improved micro hematocrit method. Am J Clin Pathol, 24(9), 1016-1024.

Terefe, G., Lacroux, C., Prévot, F., Grisez, C., Bergeaud, J. P., Bleuart, C., . . Jacquiet, P. (2009). Eosinophils in Haemonchus contortus-infected resistant and susceptible breeds of sheep: abomasal tissue recruitment and in vitro functional state. Vet Parasitol, 165(1-2), 161-164. http://dx.doi.org/10.1016/j.vetpar.2009.06.041

Terrill, T. H., Miller, J. E., Burke, J. M., Mosjidis, J. A., \& Kaplan, R. M. (2011). Experiences with integrated concepts for the control of Haemonchus contortus in sheep and goats in the United States. Vet Parasitol, http://dx.doi.org/10.1016/j.vetpar.2011.11.043

Urban, J. F., Noben-Trauth, N., Donaldson, D. D., Madden, K. B., Morris, S. C., Collins, M., \& Finkelman, F. D. (1998). IL-13, IL-4Ralpha, and Stat6 are required for the expulsion of the gastrointestinal nematode parasite Nippostrongylus brasiliensis. Immunity, 8(2), 255-264.

van Wyk, J. A., \& Bath, G. F. (2002). The FAMACHA system for managing haemonchosis in sheep and goats by clinically identifying individual animals for treatment. Vet Res, 33(5), 509-529. http://dx.doi.org/10.1051/vetres:2002036 
Veneziano, V. (2004). [Control of gastrointestinal strongyles in goats]. Parassitologia, 46(1-2), 245-250.

Vlassoff, A., Bisset, S. A., \& McMurtry, L. W. (1999). Faecal egg counts in Angora goats following natural or experimental challenge with nematode parasites: within-flock variability and repeatabilities. Vet Parasitol, 84(1-2), 113-123.

Wharton, D. A. (1982). The survival of desiccation by the free-living stages of Trichostrongylus colubriformis (Nematoda: Trichostrongylidae). Parasitology, 84(Pt 3), 455-462.

Wharton, D. A. (1991). Ultrastructural changes associated with exsheathment of infective juveniles of Haemonchus contortus. Parasitology, 103, 413-420.

Wharton, D. A., \& Sommerville, R. I. (1984). The structure of excretory system of the infective larva of Haemonchus contortus. Int J Parasitol, 14(6), 591-600.

Woolaston, R. R., \& Baker, R. L. (1996). Prospects of breeding small ruminants for resistance to internal parasites. Int J Parasitol, 26(8-9), 845-855.

Wynn, T. A. (2003). IL-13 effector functions. Annu Rev Immunol, 21, 425-456. http://dx.doi.org/10.1146/annurev.immunol.21.120601.141142

Zarlenga, D. S., Dawson, H., Kringel, H., Solano-Aguilar, G., \& Urban, J. F. (2004). Molecular cloning of the swine IL-4 receptor alpha and IL-13 receptor 1-chains: effects of experimental Toxoplasma gondii, Ascaris suum and Trichuris suis infections on tissue mRNA levels. Vet Immunol Immunopathol, 101(3-4), 223-234. http://dx.doi.org/10.1016/j.vetimm.2004.05.003

Zaros, L. G., Bricarello, P. A., Amarante, A. F., Rocha, R. A., Kooyman, F. N., De Vries, E., \& Coutinho, L. L. (2010). Cytokine gene expression in response to Haemonchus placei infections in Nelore cattle. Vet Parasitol, 171(1-2), 68-73. http://dx.doi.org/10.1016/j.vetpar.2010.03.020

Zhao, A., McDermott, J., Urban, J. F., Gause, W., Madden, K. B., Yeung, K. A., . . Shea-Donohue, T. (2003). Dependence of IL-4, IL-13, and nematode-induced alterations in murine small intestinal smooth muscle contractility on Stat6 and enteric nerves. J Immunol, 171(2), 948-954. 